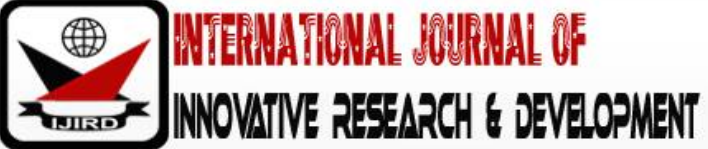

ISSN 2278 - 0211 (Online)

\section{The Life and Choral Works of a Music Educator: Dr. Geoffrey Stephen Boateng}

\author{
Augusta Arko-Mensah \\ Lecturer, Department of Music Education, University of Education, Winneba, Ghana
}

\begin{abstract}
:
The study of the life and works of musicians in Africa has received little attention with paucity of literature on them. In music education, most of these studies are relevant to give exposure to the allegories of musicians whose works have played important roles in the socio-economic development of the society. One of such musicians in Ghana is Dr. Geoffrey Stephen Boateng of blessed memory. He has distinctive choral music which has implications for educational practice. Through interview and document search, the study unravels his life and choral works as a contribution to the literature on Ghanaian and African art music composers. The study also highlights his works as educational materials for music educators and all in the cognate disciplines. It is concluded that Boateng's works can aid in the teaching of the various aspects of music to enhance creative thinking in music. It is therefore recommended that music educators use materials of such nature in their class while more research continues in this area of study to establish diverse styles in African art music compositions.
\end{abstract}

Keywords: Geoffrey Stephen Boateng, music education, Presbyterian, creative arts

\section{Introduction}

There are growing researches on the life and works of outstanding art musicians in Ghana and how their music has contributed to the various facets of socio-economic development in the society. Agawu (1984/1987) wrote on the works of Amu, Dor (2005) also wrote on Amu, Blege and Dor, Amuah (2012) researched on George Worlasi Kwasi Dor, Nicodemus Kofi Badu and Newlove Annan while Wiggins (2005,) had an interview with Nketia and his life .Undoubtedly, composers such as Ephraim Amu and Nketia have received much recognition in the art music with little exposure of some other art musicians whose works are vivifying. One of such art music composers is Dr. Geoffrey Stephen Boateng of blessed memory. Although, there are pieces of information about him in textbooks and on the internet, such information does not position him well within music scholarship. Geoffery is one of the art music composers in Ghana, among others such as Gaddiel R. Acquaah, Allotey- Pappoe, Ephraim Amu, Otoo Boateng and I.D. Riverson who have indeed contributed tremendously in providing hymns for our churches and composing short anthems, comprising secular, patriotic and sacred songs. These compositions became part of the cultivated culture of Ghanaians and the Christendom.

In recent times, some of these pieces created by these composers seem to be facing extinction as a result of the emergence of burger highlife, hip-hop, rhythm and blues, gospel songs and other pop styles. Many children, the youth as well as the elderly, seem to be involved in today's type of music. Meanwhile, Ghanaian Christian (orthodox) churches have inherited a rich tradition of hymnody from the West which could also be implored in the teaching and learning of music in our schools in addition to the already existing ones. In this regard, one of the ways to preserve them is to use them as teaching materials in our various classroom situations. As rightly stated, Taylor (2003) made the assertion that culture is that complex whole which includes other capabilities and habits acquired by man as a member of society. This idea goes to emphasize culture as a body of ideas and knowledge to be handed down and education is seen as the means to help in the accurate assimilation of this corpus. The elements inherent in the music of Geoffery Boateng, therefore, are good material to serve this purpose through formal education.

Indeed, many scholars have given exposure to the significance of music (Acquah, 2016; Acquah et al. 2015; Taylor, 2010; Reimer, 2009; Batt-Rawden et al. 2005; Stokes, 1997). Thus, music has been essential to man throughout history and is equally important today because of its power to unite and solidify social groups. Early interaction with music, therefore, positively affects the quality of all children's lives, as such; music is a natural and important part of young children's growth and development. The selection of musical repertoire for teaching and learning at these levels must be carefully examined to suit the totality of their human endeavours, needs and aspirations. Geoffery Boateng's contribution to Ghanaian art music is not only found in the composition of songs but as a scholar musician, he had been engaged in music education, having also been involved in the drawing up of the basic school music syllabuses and being in charge of music courses for principal teachers in Ghana. The study therefore makes incursion into his life and works and gives important information on his works that will be pertinent for use in the classroom. 


\section{Theoretical Framework}

The study was based on the theory by Bruner (1966) learning is an active process in which learners construct new ideas or concepts based upon their current or past knowledge. Bruner id of the view that the learner proceeds from the known to the unknown and that new knowledge is built upon prior experience. This belief transfers into education in the form of a spiral curriculum wherein the basic elements are revisited throughout the students' years of study in an everincreasing complexity. The theory explains that the learner selects and transforms information, constructs hypothesis and makes decisions, relaying on a cognitive structure to do so (that is, scheme, mental models). These provide meaning and organization to experiences and allow the individual to go beyond the information given. Bruner goes further to explain that a theory of instruction should address four major aspects thus: 1 . predisposition towards learning 2 . the way in which a body of knowledge can be most readily grasped by the learner 3. the most effective sequences in which to present material and 4. the nature and pacing of rewards and punishment

A number of writers have proposed developmental guidelines that have informed me as to the teaching of composition in this classroom (such as Bruner, 1960, Wolf and Gardner, 1980). Their works have substantiated the need to focus on existing works to create new and novel works of students. In this regard, the life and works of Geoffery Boateng will provide a foundation for innovation of compositional skills in the classroom and advance creativity in pupils' compositions. Reading the work of other researchers (Kratus, 2007; Gromko, 2005; Smith, 2002; Blackburn et al., 1998) has also helped to formulate my questions and influence my decisions concerning composition in the classroom. For example, Barrett (1997) provided new questions important in an educational setting, such as whether or not the process of composition should necessarily be judged by the resulting product. While some research such as Kratus (2007),

Barrett (2006), and then, Swanwick and Tillman (1986) focused on individuals or small groups of children, others like and Hamilton et al. (2008), Wiggins and Kobom (1992) and Small et al. (1990) have provided with structures for composing in whole class situations. As a result of studying these and other sources, the goal of this research is to provide relevant teaching materials to facilitate student musical exploration and invention through developmentally appropriate compositional strategies that might act as scaffolding for natural development of compositional techniques and skills using the works of Geoffrey Boateng as musical examples in music creative activities.

\section{Review of Related Literature}

The colonial legacies of education have remained with Ghana since independence in 1957 and from 1987 to date. Massive reforms have been carried out to make Ghanaian education more feasible in terms of values, beliefs and cultural identity. Throughout the history of music education in Ghana, scholars have expressed concern about the way music is detached from the Ghanaian child's environment and culture and have called for review. Flolu (2003) for instance stated that though the music programme in Ghana does not include modern composers of the West (the study of Western classical music in Ghanaian schools covers the periods from 17th to 19th centuries)'. So far, there has been the tendency to limit the relationship with the world to Europe. This has led us to neglect the contribution which the music and musicians of other African countries could make to the development of music education in Ghana, and indeed in individual African countries. For example, Nigeria and Ghana have recently developed secondary school music programmes each based on the music and composers of their respective countries.

A close study of publications indicate that most researchers take delight in writing and compiling information about politicians and public figures forgetting about prolific musicians and the part they have played towards nation building and development in most of our African countries including Ghana. We can give few examples as Kwame Nkrumah: a biography by Milne (2000), Rawlings Factor Shillington (1992). This book tells a dramatic story of two popular revolutions in one country, Ghana, both of them led by the same man, then a dashing young flight lieutenant named Jerry John Rawlings. It traces the history of those turbulent years, assessing its triumphs and its failures. Central to the book, however, is the Rawlings' factor: that remarkable leader whose influence and importance can never be ignored, a man who arouses emotions in both opponents and admirers. Nevertheless, there is paucity of literature about musicians, specifically, art music composers although few of them have received some attention in the academic circle as already stated. Few of them also have their musical profiles scattered on the internet and newspapers. In a study on Professor Kwabena Nketia by Akrofi (2002) for instance, a profile of Kwabena Nketia as scholar and music educator was expounded. His biographical study is presented in two parts: one part deals with his educational background and his work as a teacher and scholar and part two is devoted to the educational value of his source materials, such as his books on African musicology, his thoughts on music education found in his article and the practical application of ethnomusicology and composition in his pedagogical pieces and exercises in African rhythm.

Sandler (2019) also wrote extensively on Dr. Ephraim Amu delineating how Amu is presented as a man of varied qualities of selflessness, originality and regard for African-ness which characterized the life of this renowned Ghanaian educationist and reformist. The book sought to inspire the youth to emulate the good example of Dr. Amu - a personality who has influenced for good many pupils and students in his 50 years of teaching. It is upon these thoughts that Geoffery Boateng, who spent most of his life in music education and whose works have implications for educational practice needs to be studied to encourage other scholar composers and enhance creativity in the classroom.

\section{Methodology}

This study adopted the case study approach. Like Runeson et al. (2012) explained, a case study is an appropriate research design when you want to gain concrete, contextual, in-depth knowledge about a specific real-world subject. It allows you to explore the key characteristics, meanings, and implications of the case. The study sought to detail the life of Dr. Stephen Geoffery Boateng and his choral works. In dealing with the subject of the study, three sons and the 
only surviving sister of Geoffery were purposively selected for the study while his funeral brochure and musical scores were also selected and analyzed. 'Purposive sampling is a sampling technique in which researcher relies on their own judgment when choosing members of population to participate in the study (Sharma, 2017, p. 752). The participants selected were well connected with the life and musical works of their father. Two of them are ministers of the gospel in different denominational churches and might have been using some of his songs in their churches. Some information was also found from the internet to crosscheck the primary data collected. The respondents were interviewed at different times in their residence. The information gathered included his birth, early life, how he acquired his musical talent as well as his career as a musician. His works were also analyzed to determine the style, choice of his texts, and how his works can be used as educational materials in the classroom. His musical scores which were handwritten were rescored using the Music software; Finale 2012 and printed out. These musical pieces were played to determine its simplicity to be used at any level of music education while the texts were studied for its suitability in education.

\section{Discussion of Findings}

The results of the findings were discussed according to his birth, development of his musical talent, his life as a music teacher and a choral director and his music and its educational utilization

\subsection{His Birth}

In Ghana and Africa as a whole, music does not only function as an accompaniment to various activities but it is also for entertainment (Hargreaves et al., 1999). Stress is placed upon musical activity as an integral and functioning part of the society. Such is the kind of society that young Geoffrey Boateng found himself in. Both secondary and primary sources revealed some inconsistencies in his birth date. The date of birth of Boateng has been somewhat controversial. Some researchers stated that he was born on 1st October, 1925 while others claim he was born in 1926. A scholar stated that he was born in 1925 (Aduonum, 1993) while Agordoh (1994) and Manford (1996) mentioned that Boateng was born in 1926. Agordoh and Aduonum agree on the place of birth at Adukrom, Akwapim and of the same parentage as Boateng and Sika Christiana. The different birth dates in the accounts above are very significant to the study since it points out the inconsistencies in our history and opens the curiosity of the researcher.

Incredibly, the document study of his funeral brochure of his burial and thanksgiving service programme dated Saturday, 29th July, 2000 indicated that Boateng was born at Adukrom-Akwapim on the 1st of October, 1923. His parents were Mr. Ammishaddai Abeate and Madam Christiana Sika, both of Adukrom. This was also confirmed by his elder sister Madam Odeibea, in an interview I had with her at her residence in Madina, Accra:

The correct date of birth of Boateng is 1st of October, 1923 as you found in the brochure. Our father was a teacher and a self-taught musician/organist who started the Akwapim Adukrom branch of the Presbyterian Singing Band after the First World War in the early 1920's while our mother was Christiana Sika also of Adukrom Presbyterian Singing Band. She was a soprano singer and a trader. (Odeibea)

Suffice to say that the age differences given by the scholars and the primary data could be attributed to a known fact that most Ghanaian civil servants tend to cut down their dates of birth to enable them spend or serve longer years at their work places. It is palpable that Geoffrey Boateng was caught in that situation.

\subsection{Development of his Musical Talent}

It was found out that Boateng was born to parents who were musically inclined. Boateng was taught how to sing several religious songs, folktale songs and children's songs which he loved most. As a result of this, he found himself in several children's musical activities at church, school, home and in the community. He was also taught how to sing several songs by his parents especially his mother, Sika, who was a lover of music. Like his sister postulated,

Boateng was always heard singing while he was left alone to mind his business. (Odeibea)

This assertion is confirmed in his late wife's tribute to him that 'your tenor voice wherever we sang together during morning devotions shall never be forgotten' (Obituary Brochure, 2000). This is corroborated by Dawling and Hardwood (1942):

During his or her early impressionable years, the child becomes familiar with music by being exposed to it in his/ her daily life and more or less unconsciously absorbing it from his or her surroundings. He/she finds joy in expressing himself/herself and in creating things that give him/her pleasure. Thus, he or she begins to lay the foundation not only in music but also of attitudes towards individual and group endeavor, discipline and achievement. (p. 42)

It shows Boateng's flare for singing even unto death. Throughout primary and middle years in both Adukrom and Akropong, Boateng showed exceptional talent and sensitivity to music and dance. He learnt to sing Western songs and church hymns and also during the middle school years he was responsible for giving the pitch for songs during singing practices. It was therefore not a surprise when he started singing Nketia's solo songs in later years with his rich tenor voice.

He, thus, played a very significant role in the school's musical activities as narrated by his sister. The researcher also found out that after his elementary education, Boateng popping up with musical interest enrolled at the Presbyterian Training College at Akropong in 1940. It was here that he met Revds. Dr. Otto Boateng and R. O. Danso as his music tutors. In addition to these great musicians, Boateng had the opportunity of studying more music with Prof. Kwabena Nketia and N. Z. Nayo who were also senior students of the college at that time. In 1963, Geoffrey Boateng was sent to Germany to do a three-month Youth Music Education course. On his return, he was again offered a scholarship to further his musical studies in Leningrad, Russia, from 1963 to 1967. There, he studied under the Hungarian music educationist; Zoltan Kodaly 
who assisted him to obtain his Bachelor of music degree. From Russia, he pursued another three-month music course at the trinity college of music, London, where he did music theory, conducting, choral and orchestral studies obtaining the licentiate in music (LTCL). In 1980, Geoffrey Boateng was back again at the Trinity College of Music, London to complete his research thesis titled 'Ghana Folk Songs and Music Instruments and their bearing on Contemporary Music Education which he successfully complete.

\subsection{Life as a Music Teacher/Choir Director}

In 1946, Geoffrey Boateng was posted to Kumasi Presbyterian Primary School as a teacher where he met music educators such as I.D. Riverson, then teaching at Prempeh College, J. H. Alhassan, an organist at St. Peters church and D. F. Nzeh, also an organist at the Wesley Methodist Church all in Kumasi. In order to solidify his musical background for future use and dissipation, Boateng in 1949 furthered his musical studies by enrolling at the Achimota Teacher Training College under the musical directorship of Dr. E. Amu who started this first of its kind 3-year School of Music in the country in 1948. Boateng had Charles Graves Jnr., Adu Safo, N. Z. Nayo. Frank Nyarko, J. M. T. Dosu, J.S. Maison and Prof. A. A. Mensah as classmates. Completing his music at the Achimota Training College in 1951, Boateng took up an appointment as a music tutor at the Presbyterian Secondary School, KroboOdumase, where he devoted his attention to the school choir and subsequently formed the Orpheus choir, and it was around this time that his 'Rudiments of Music grade 1' was published in London. In 1960, Geoffrey Boateng joined the staff of St. Monica's training college, Asante-Mampong.

In 1961, Boateng organized a one hundred and forty (140) member strong choral group which performed at the Great Hall of the University of Ghana as part of Ghana's Republic Day Celebration. The repertoire included 'Monkamfo no' by Nketia, 'Adowkyekyekye' by Riverson 'Momma yenkosomforo', and 'yen araasaaseni' by Amu. The success of this concert became a hallmark in Boateng's professional music career. Later on, in the same year, he became a music critic for the Ghana Broadcasting Corporation. Similarly, in 1965, while in Leningrad, U. S.S. R. to do further studies in music, Boateng had the opportunity of conducting Benjamin Britten's War Requiem in the presence of the composer with tumultuous success. In 1973, Stephen Geoffrey Boateng became the first Deputy Director of the National Academy of Music in Winneba. It was around this period that he was seconded to the arts Council of Ghana as secretary to the national music association.

In 1977, Geoffrey represented Ghana as a choral conductor at the 2nd World Black and African Festival of Arts and Culture in Lagos, Nigeria. Here, he was awarded a certificate of Honour in recognition of his role in the overall success of Ghana's contribution to the festival. Boateng lectured choral and instrumental groups and organized choral competitions in many parts of the country with the aim of improving the quality of singing. It was out of such programmes that in 1983 he wrote and published the book Read and Write Music Grade One for primary class one. This book was published in London.

In 1967, he taught music at the Specialist Training College in Winneba. When the music Department was separated from the College and became the National Academy of Music in 1973, Geoffrey Boateng became the first Deputy Director until he was seconded to the Arts Council of Ghana as Secretary to the National Music Association. Dr. S. G. Boateng, 'Boat' as he was affectionately called by his colleagues, was an excellent music teacher. He was employed as lecturer at the Music Department, University of Ghana, Legon, in 1976 and served in that capacity for twenty years and later as a part-time lecturer in 1996, a position he held until he passed away in June, 2000. Dr. Boateng was a great pillar of support to the music programme at the University of Ghana, where he taught composition related courses such as Harmony and Counterpoint, fugue as well as Musicianship. He was a delightful and devoted teacher often combining fairness, firmness and strict discipline tempered with infectious humour and ready wit.

By popular opinion, Geoffrey was easily one of the most outstanding conductors this country has ever known. He was also an excellent choir director and composer. He would always be remembered for his role in the development of choral music in Ghana and be greatly missed for his contributions at choral festivals and workshops. As reported in his funeral brochure by Dr. Asante-Darkwah, Boateng's commitment and dedication to duty should serve as a good example to his colleagues and his many students of music. It is for these reasons among many others that this good and peaceful man needs to be forever remembered through the composition of songs and his contribution to the development of education in Ghana. Geoffrey Boateng was the brain behind the formation of the Ghana Association of Choral Conductors. As secretary of the association, he was invited to attend the international choral conductors' conference in Sweden in 1990.

Due to an indication of his stature as a music educator, he was awarded an honorary doctorate degree by the World Univeristy Roundtable in 1984. From the 27th of July to the 6th of August, 1992; Boateng attended the 16th Zimriya World Assembly of Choirs in Israel as a guest conductor. There, he went on an excursion with other participants to Nazareth, a Kibbutz and the Holy Places around the Lake of Galilee. In his teaching, he would not hesitate to go near a student playing the piano whenever he heard a wrong note, phrases and rhythms being played. This was a man who really loved his work as a teacher. Although he stammered, there were times when students never thought he ever stammered since he was so friendly, sociable, and easily approachable. Most students admired him for his controlled temper and they really wanted to always be in his company. He was indeed a father to all the students. 


\subsection{His Music and Its Educational Utilization}

In all, twenty-four (24) of his songs were collected and scored with the titles.

\begin{tabular}{|c|c|c|}
\hline $\mathbf{S} / \mathbf{N}$ & Song Title & Translation \\
\hline 1. & Asomdwoe aba & There is peace \\
\hline 2. & Abena oni awu o & Abena's mother is dead \\
\hline 3. & M'ase, gya me ha e & My in-law, leave me here \\
\hline 4. & Nana aberwa nye me & I am an old lady \\
\hline 5. & Agya Ananse & Father Ananse \\
\hline 6. & Anuonyam wo sorosoro & Glory in the highest \\
\hline 7. & Ao, bra & Please come \\
\hline 8. & Ehurusi ndwom & Happy song \\
\hline 9. & Esono Kwarten & Kwarten is different \\
\hline 10. & Hena na ogyina hว? & Who is standing? \\
\hline 11. & Nana Kyekye & King give away \\
\hline 12. & Makeka mmoa nyina srade ma muntum & Taste the fat of all animals \\
\hline 13. & Me tire kae kae me & My head, remind me \\
\hline 14. & Me ba baako nkyer oo & My only child \\
\hline 15. & 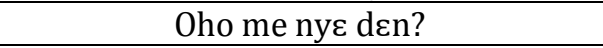 & No, what should I do? \\
\hline 16. & Miva ne mia yi Bethlehem & Let's go to Bethlehem \\
\hline 17. & Momma Abena nkonko nsoa & Let Abena alone carry \\
\hline 18. & Music the soul of man & \\
\hline 19. & Mo nnipa & Well done, man \\
\hline 20. & Se me ara & It's up to me \\
\hline 21. & Эує Ogya & He is fire \\
\hline 22. & Agya Jsebs & Father Tiger \\
\hline 23. & Wo a wokro no e & You who are going \\
\hline 24. & Yen ani agye nne & We are happy today \\
\hline
\end{tabular}

\section{Table 1}

His compositions were mainly religious and pseudo-religious. Some characteristics of his songs such as ehurusi ndwom (happy song) and yen ani agye nne (we are happy today) which have since the 1950s become popular anthems with most choral groups in the Presbyterian church, are their lively beat, beautiful harmony and arrangement. The texts of Boateng's songs reflect his experiences and inner life. An example is M'ase gya me ha e (My in-law, leave me here).

\subsubsection{Example 1: M'ase gya me ha e}

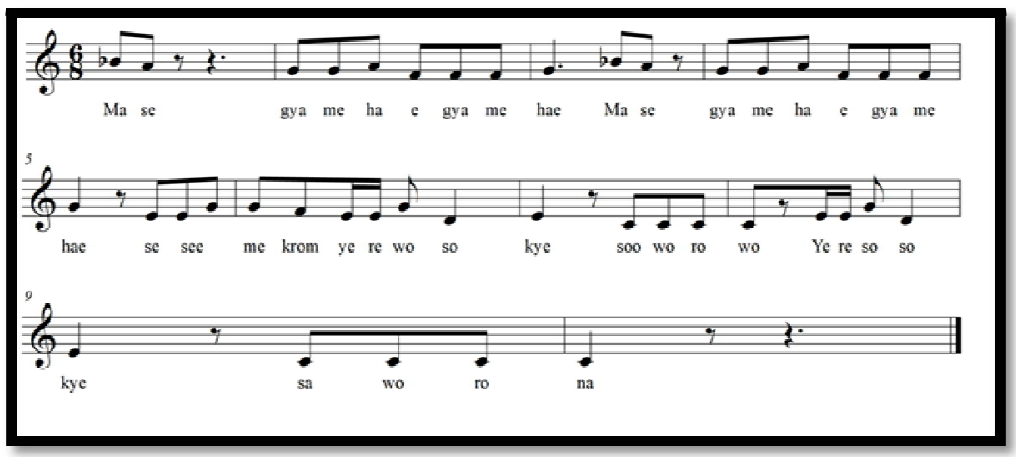

Figure 1

His sense of feeling towards man and service to his fellow man takes precedence in his compositions. His melodies are very simple without much chromatics and frequent key changes, thus, young children as well as adults can conveniently learn, sing and enjoy the music as exemplified in the following: 


\subsubsection{Example 2: Abena Oni Awuo}

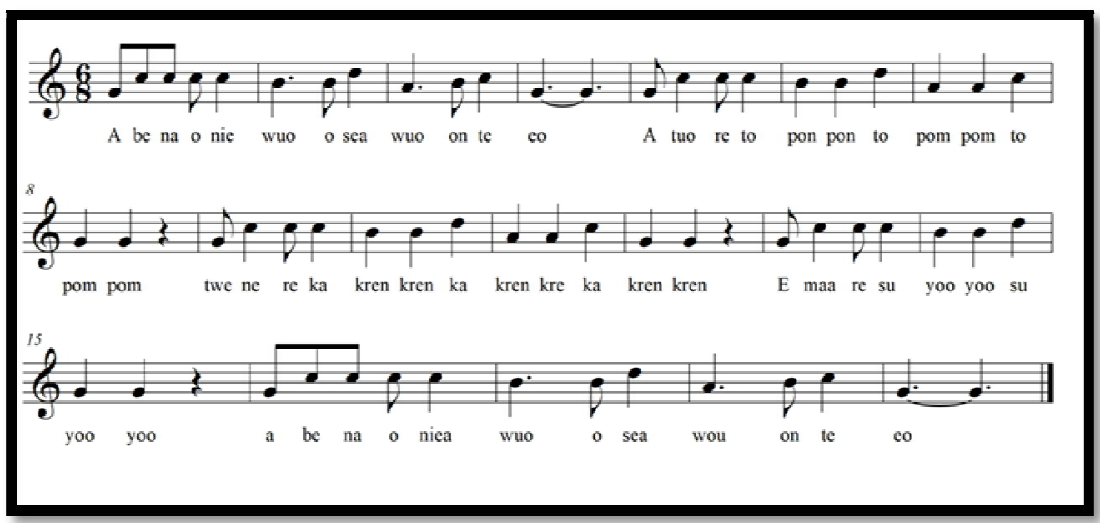

Figure 2

\subsubsection{Example 3: Esono Kwarten}

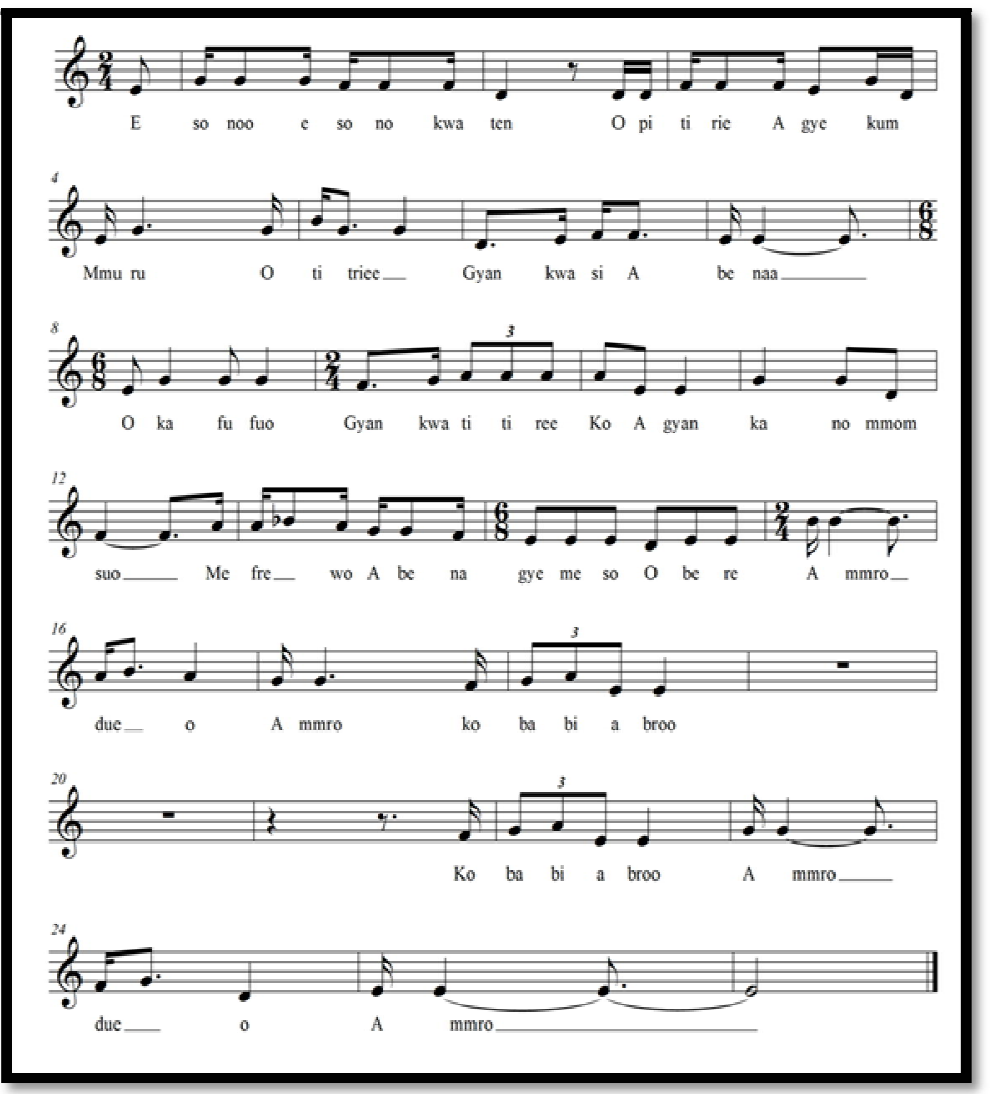

Figure 3

He was an excellent composer. It is interesting to note that as an organist, singer and conductor who could easily play the organ using the tonic sol-fa as well as the staff to the admiration of his colleagues and students so well that this greatly influenced his kind of compositions.

Specifically, the unique nature of music gives satisfaction to children long before they go to school. This is in agreement with what Reimer (1989) states that: 'music has the power of evoking feelings which are important to the child's knowledge of beauty' (p.20). As the child is allowed to express his or her feelings through musical activities, he or she automatically learns to make decisions and judgments about music'. From the activities which children perform in the form of singing, playing instruments, composing, moving and listening to every child can find one or two of these activities which can be enhanced by the teacher. Furthermore, the nature of music and its classroom activities foster socialization more than any subjects taught in school (Small et al., 1990). Geoffery Stephen Boateng uses a variety of traditional and popular sources as the basis of his compositions. As in traditional African practice, each piece can be repeated once or twice except where a definite closure is indicated. Mainly, Geoffrey Boateng uses tonal harmony in his pieces where the harmony is based on the use of well-structured chords and their progressions of the Western 18th century compositional harmonic styles as found or exhibited in hymn singing. The melodic lines of most of his pieces are derived from Ghanaian folk tunes with regards to both the inflections of speech and rhythm of the language. There is no child who has not sung or 
reacted to singing. For that matter a basic school teacher must have a repertory of appropriate and suitable songs at his disposal at all times for effective teaching and learning of music in our schools.

The Creative Arts Syllabus which was launched in September 2008 by the government, and the, Ghana Education Service, seeks to promote the diverse aspects of our culture. In recent times, Ghana has embarked upon a constructive national transformation programme which demands identification of important areas of national development such as agriculture, industry, science and technology, education, health, culture, democracy and the economy. A very crucial element for national development is national creativity. However, creativity should be fostered through other subjects in the curriculum. The main focus of Creative Arts is critical and creative thinking and responding to performance, problem solving and socio - economic progress. Accordingly, the programme creates an avenue for students to actively participate in creative or in artistic process (singing, playing an instrument, drawing, carving, acting, dancing, composition and appreciation) which enhance the growth of one's imagination and self- expression.

Creative Arts provide avenues for strengthening social identity and unity of purpose, discovering the cultural heritage and creating a unifying nation. Apart from unlocking the creative potentials of the individual, the Creative Arts are the foundation for the development of skills in Design and Technology and therefore, preparation for industrial development. The programme thus creates an avenue for all those who acquire formal education through the school system to be given the opportunity to develop the attitude and grow to be proud of their country, appreciate and reckon with their culture and also have the urge to serve others. Not only should children recognize our cultural heritage but should uphold it in high esteem. The cultural norms, beliefs and values and all those aspects which are very beneficial and contribute to national development should be fostered by transmitting them to children. This, however, can be made possible by equipping children with these values through the teaching of African drumming and dancing including contemporary Art songs and singing. Geoffrey Boateng's music which has these elements can therefore serve as a source of reference for this programme.

Since music predominately consists of arrangement of sound and silence (Bradley, 2001), it is logical to start teaching rhythm by making the children explore sound and its many dimensions. Rhythm is found in nature, art, speech, movement and everyday life. Rhythm in music includes everything pertaining to the movement and duration of the musical sounds. In listening to and singing songs like 'Ehurusi Ndwom' different sounds can be created by the children. For example, it is possible to make sounds by clicking fingers, clapping fingers, hands tapping and stamping of feet on the floor. Research, has shown that children learn through observation, imitation and experimentations (Piaget, 2015), thus in a composition class child could be made to substitute different text for this same Ehurusi Ndwom melody and so on. Children can be made to compose pieces using, those of Boateng as examples and play improvisations on the pieces composed. It can be used to form ensembles where children are divided into groups and play pieces or sing the main melody while others accompany with other instruments available in class.

An aspect of the Creative Arts Syllabus is the promotion of drama and dance. Some of Boateng's songs lend themselves towards dramatization. Children can be asked to take themes from some of his songs and compose a storyline against these melodies or vice versa. Boateng's melodies can be seen as very simple in terms of the rhythmic structure. The use of a combination of crochets, quavers and minims is prominent in his melodic patterns. By teaching the children to perform these sample melodies, they could be guided to compare in similar vein. The songs are so simple that elements such as rhythms, sequence and intervallic structure can be taught to children within a short period. Swanwick et al. (1986) listed five parameters of music which are acquired through musical learning situations. Those include composition, literature studies, audition, skill acquisition and performance. Swanwick et al. argued that the teaching of music in the classroom or outside the classroom must be created for in these parameters. In the case of literature studies, contemporary Art Composers could be studied.

Some art songs recorded on CDs can be played to children whilst they listen carefully and make their observations by expressing how they feel about Geoffrey Boateng's music as compared to other Ghanaian art composers like J. M. T. Dosoo, Pappoe-Thompson, A. A. Mensah and M. K. Amissah, to mention a few. Composition of various forms either in the traditional choral style, instrumental or any medium could be enhanced. Children through this acquire various performance techniques in the art of presentation through solo performance, ensemble participation and other aesthetic musical art. Apart from composition and performance which constitute the bedrock of the Creative Arts Syllabus of the Basic Schools, there is the perception and conceptualization factor. This actually depends on the amount of listening that a child will do. After listening to Geoffrey Boateng's music very critically one can make analytical study in describing the form of the music, the melodic contour and make observations as to the mood of the music. In totality the child's perception and concept about composition will be greatly enhanced.

The music of Geoffrey Boateng can be seen as something that has a lot to offer the child at the basic school level. Since his music forms part of the environment into which the child grows, it becomes a readily available material for a formal classroom or learning process. Although the situation outside the classroom may be different in terms of assimilation, the classroom provides a very conducive atmosphere or environment through which materials of Boateng's music can be presented in a graded form. The child needs to be assisted to appreciate the music around him in terms of indigenous traditional music and contemporary art songs into which he was born. In the community, he is exposed to so many things but in the formal classroom set up, materials are selected within the child's competence. Our traditional music as well as other types of highlife and contemporary art music makes us to be recognized as Ghanaians. If a child learns to sing these art songs, it enables him to understand music theory; explicitly learning and writing of music therefore can be seen as useful in terms of having access to them just as our language. Writing in actual fact helps us to recall. Kwami (1994) argues that we start learning even before we start to write and when it comes to music reading and writing it is better to expose the child to his own music very early so that he grows up with it to be able to write it. 
Geoffrey Boateng's music, nevertheless, can be seen as having all the elements that can help in teaching almost every aspect or elements of music the child needs to know at the basic level. The text of Boateng's music offers a very rich language of oratory which actually places one in a certain class of wisdom. The poetic nature and proverbial choice of words with accompanying message of moral thought are essential for the growth of the individual at the basic school level.

\section{Conclusion}

The whole music of Geoffrey Stephen Boateng can be seen as a treasure that has a lot to offer the child at the basic school level. Since his music forms part of the environment into which the child grows up, it thus become a readily available material for a formal classroom teaching and learning process. The life of the man Geoffery Stephen Boateng well as his deep roots in hymnody and spiritual (shouts) music upholds a sense of nationalism for our younger generation to emulate. His contribution to Ghanaian art music is not only found in the composition of songs but as a qualified musician, he was been engaged in music courses both at Saltpond and Accra for former principal teachers. Geoffrey Boateng strove hard to rub shoulders with great masters like Ephraim Amu, Otto Boateng, J. H. Nketia and Zinzendorf Nayo. His choral compositions were often included in the repertoire of many choirs and singing bands in Ghana. Although Geoffrey Boateng was brought up as a staunch Presbyterian, he later defected to the Feden Church which had Rev. Yeboah Koree as its founder and leader. Here he was charged to write songs for the various singing groups in the church. Although he was in charge of the singing band, whenever a group had a serious programme like celebrating an anniversary or going for a singing composition with sister choirs, Boateng was commissioned to write songs to be used. He had good musical ears and was able to memorize all parts of most of the songs he taught though he was a tenor singer. This makes Geoffrey stand out as an intelligent art music composer whose life and music exemplify him as an icon of choral music of his time.

\section{References}

i. Acquah, E. O. (2016). Choral Singing and Wellbeing: Findings from a Survey of the Mixed-Chorus Experience from Music Students of the University of Education Winneba, Ghana. Legon Journal of the Humanities, 27(2), 113.

ii. Acquah, E. O., Sackey-Sam, K. A., \& Annan, J. F. (2015). Use of indigenous musical games and songs in developing the total well being of the child. International Journal of Research, 112.

iii. Aduonum, A. O. (1993). Musical Continuity and Change in Ghanaian Drumming Instruction in the United States of America: A Case Study of Kwasi Aduonum (Doctoral dissertation, Florida State University).

iv. Agawu, V. K., \& Amu, E. (1987). The making of a composer. The Black Perspective in Music, 51-63.

v. Agawu, V. K. (1984). The impact of language on musical composition in Ghana: An introduction to the musical style of Ephraim Amu. Ethnomusicology, 28(1), 37-73.

vi. Agordoh, A.A. (1994). Studies in African Music. Ho, Ghana. New Age Publication.

vii. Akrofi, E. A. (2002). Sharing Knowledge and Experience. Afram Publications (Ghana) Ltd.

viii. Amuah, J. A. (2012). The use of traditional music elements in contemporary Ghanaian choral music: Perspectives from selected works of George Worlasi Kwasi Dor, Nicodemus Kofi.

ix. Badu and Newlove Annan. Unpublished Ph. D Thesis, University of Ghana, Legon.

x. Barrett, M. (2006). 'Creative collaboration': an 'eminence' study of teaching and learning in music composition. Psychology of Music, 34(2), 195-218.

xi. Batt-Rawden, K. B., DeNora, T., \& Ruud, E. (2005). Music listening and empowerment in health promotion: A study of the role and significance of music in everyday life of the long-term ill. Nordic journal of music therapy, 14(2), 120-136.

xii. Blackburn, S., \& DeRoure, D. (1998, September). A tool for content-based navigation of music. In Proceedings of the sixth ACM international conference on Multimedia (pp. 361-368).

xiii. Bradley, D. (2007). The sounds of silence: Talking race in music education. Action, criticism, and theory for music education, 6(4), 132-162.

xiv. Bradley, L. (2001). This is reggae music: the story of Jamaica's music. Grove Press.

xv. Bruner, J. (1966). Toward a Theory of Instruction. Harvard University Press.

xvi. Dawling, W. Y. \& Hardwood, D. L. (1942). Music Cognition. Oxford.

xvii. Dor, G. (2005). Uses of indigenous music genres in Ghanaian choral art music: Perspectives from the works of Amu, Blege, and Dor. Ethnomusicology, 49(3), 441-475.

xviii. Flolu, J. (2003). An introduction to music education in Ghana for universities and colleges. Black Mask Limited.

xix. Gromko, J. E. (2005). The effect of music instruction on phonemic awareness in beginning readers. Journal of research in music education, 53(3), 199-209.

xx. Hamilton, J. T., \& Hamilton, J. (2008). Music, Madness, and the Unworking of Language. Columbia University Press.

xxi. Hargreaves, D. J., \& North, A. C. (1999). The functions of music in everyday life: Redefining the social in music psychology. Psychology of music, 27(1), 71-83.

xxii. Kratus, J. (2007). Music education at the tipping point. Music educators journal, 94(2), 42-48.

xxiii. Kwami, R. (1994). Music education in Ghana and Nigeria: A brief survey. Africa, 544-560.

xxiv. Manford, R. (1996). A Handbook for Primary School Music Teachers. Accra: Sam-Woode Ltd.

xxv. Milne, J. (1999). Kwame Nkrumah: a biography. Panaf.

xxvi. Piaget, J. (2015). The Grasp of Consciousness (Psychology Revivals): Action and Concept in the Young Child. Psychology Press. 
xxvii. Reimer, B. (2009). Seeking the significance of music education: Essays and reflections. R\&L Education.

xxviii. Reimer, B. (1989). A Philosophy of Music Education. Prentice -Hall: New Jersey.

xxix. Runeson, P., Host, M., Rainer, A., \& Regnell, B. (2012). Case study research in software engineering: Guidelines and examples. John Wiley \& Sons.

xxx. Sandler, F. (2019). Ephraim Amu's African Songs: Notation and Performance Practice. The Choral Journal, 60(4), 28-45.

xxxi. Sharma, G. (2017). Pros and cons of different sampling techniques. International journal of applied research, 3(7), 749-752.

xxxii. Shillington, K. (1992). Ghana and the Rawlings factor. Macmillan Small, A., Wiggins, G., \& Harris, M. (1990). Hierarchical music representation for composition and analysis. University of Edinburgh, Department of Artificial Intelligence.

xxxiii. Smith, S. C. (2002). A Heart at Fire's Center: The Life and Music of Bernard Herrmann. Univ of California Press.

xxxiv. Stokes, M. (Ed.). (1997). Ethnicity, identity and music. Oxford: Berg.

xxxv. Swanwick, K., \& Tillman, J. (1986). The sequence of musical development: a study of children's composition. British journal of music education, 3(3), 305-339.

xxxvi. Taylor, J. (2010). Queer temporalities and the significance of 'music scene' participation in the social identities of middle-aged queers. Sociology, 44(5), 893-907.

xxxvii. Taylor, J. S. (2003). Confronting 'culture' in medicine's 'culture of no culture'. Academic Medicine, 78(6), 555559.

xxxviii. Wiggins, T. (2005, June). An interview with JH Kwabena Nketia: Perspectives on tradition and modernity. In Ethnomusicology Forum (Vol. 14, No. 1, pp. 57-81). Taylor \& Francis Group.

xxxix. Wiggins, T., \& Kobom, J. (1992). Xylophone music from Ghana (No. 6). White Cliffs Media Co. 